\title{
Volumetric shrinkage and shape of Conilon coffee fruit (Coffea Canephora)
}

\author{
Pedro Casanova Treto (Corresponding author) \\ Instituto de Investigaciones de Ingeniería (INII). Universidad de Costa Rica \\ Apdo. postal: 3620-60. San Pedro de Montes de Oca, San José, Costa Rica \\ Tel: 506-2511-5590Ｅ-mail: pcasanova2000@ gmail.com \\ Paulo C. Corrêa \\ Centro Nacional de Treinamento em Armazenagem (CENTREINAR) \\ Universidade Federal de Viçosa, Viçosa, MG, Brazil \\ Kattia Solís Ramírez \\ Escuela de Ingeniería Agrícola. Universidad de Costa Rica \\ Apdo. postal: 3620-60. San Pedro de Montes de Oca, San José, Costa Rica
}

Received: November 26, 2013 Accepted: December 14, 2013

doi:10.5296/jas.v2i1.4617ＵRL: http://dx.doi.org/10.5296/jas.v2i1.4617

\begin{abstract}
The effect of varying the water content was evaluated in shrinkage, dimensional characteristics and shape of the fruits of coffee during drying. Fruits were used Conilon coffee (Coffea canephora), clone 83 of clonal variety EMCAPA 8141. The fruit was hand-picked and selected only the two stages, cherry and unripe. Different batches of coffee were dried in an oven with forced ventilation with air temperature of approximately $60 \pm 3{ }^{\circ} \mathrm{C}$ until different levels of water content. Fruit size was determined by varying the volume and shape was examined by sphericity and roundness. The shrinkage of the fruits was determined by the ratio between the volume at each water content and initial volume. It was determined that the projected area, surface area and volume increase with increasing water content for conilon coffee fruit. The shape of the conilon coffee fruits was influenced during the drying process, promoting the
\end{abstract}


decrease of sphericity and roundness values from the reduction of water content. The shrinkage showed a nonlinear behavior with decreasing reducing the water content of the mass of Conilon coffee fruit. The polynomial model represented satisfactorily phenomenon of unit volumetric shrinkage and mass of coffee fruits depending on the water content.

Keywords: Coffea Canephora, Physical properties, Shrinkage

\section{Introduction}

Agribusiness coffee is among the most important socioeconomic activities when compared to different activities related to agricultural trade, with a large global commodity. The species of greatest importance in the international economic market are Coffea arabica (Arabica coffee) and Coffea canephora (robusta). About $70 \%$ of coffee traded in the world is the type arabica and $30 \%$ robusta. In the context of world coffee production, Brazil is a country located strategically better by presenting a production on a large scale of two most important species (Ivoglo, 2007).

A major factor in the success of conilon coffee due to the fact that this species is an important component in the composition of the blends with Arabica coffee. In Brazilian industries roasted and ground conilon coffee participated in 2010 , with $42.5 \%$ of the total volume consumed. This is because it has a higher soluble solids, higher industrial output, check out the feature body and structure to the final product. Importantly, the international roasters began to increase the percentage of robusta/conilon in blends from 15 to $25 \%$ for 30 to $45 \%$ (Teixeira, 2011).

Although coffee is an ancient culture, today it has developed clonal varieties with unknown physical properties, limited and scattered. The Capixaba Institute of Research, Technical Assistance and Rural Extension (INCAPER) on several years of research in the area of genetic improvement with the coffee conilon, developed five varieties of clonal and sexual propagation for the State of Espírito Santo, called respectively: EMCAPA 8111 - early maturation; EMCAPA 8121 - intermediate maturation; EMCAPA 8131 - late maturing; EMCAPA 8141 Robustão Capixaba - drought tolerant; VITORIA INCAPER 8142, and 8151 EMCAPER Robusta Tropical - of sexual propagation. These new varieties have been the basis for the renovation of coffee species in Espírito Santo and contributed effectively to the technological advancement of the culture of Coffea canephora in the whole country (Fonseca, 2001).

An important challenge to be faced by the sector of conilon coffee production is their competitiveness, which should be environmentally sustainable and economically viable. This implies offering top quality coffee to meet the markets, domestic and foreignand increasingly demanding.

Reducing the water content of the grains influences directly the change in physical properties during drying. In order to minimize costs of production for greater competitiveness and improved quality of the processed product, drying and knowledge of the behavior of physical properties of coffee fruits are the main factors contributing to the development of appropriate equipment, processes and simulations aimed improve the productive system of that culture.

Machinery projects for processing, grading and sizing equipment designed for postharvest 
agricultural products require data on the physical properties, especially the geometric properties. Information about the size, volume, density and porosity among other physical characteristics of agricultural products, are considered of great importance for studies involving mass, heat transfer and air movement in granular masses. Together with the water content, density, porosity and volume are parameters used to determine the drying conditions and storage of agricultural products and thus enable the prediction of quality losses of the material until the time of its commercialization.

The physical properties have been studied by different authors and for different agricultural products such as coffee robusta and Arabica (Chandrasekar, 1999), parchment coffee (Perez-Alegria, Ciro, \& Abud., 2001), lentils (Amin, Hossain, \& Roy, 2004), wheat (Corrêa, Ribeiro, Resende, \& Botelho, 2006), pistachio (Kashaninejad, Mortazavi, Safekordi, \& Tabil, 2006), wheat (Al-Mahasneh \& Rababah, 2007), beans (Resende, Corrêa, Goneli, \& Ribeiro, 2008), rice (Varnamkhasti et al., 2008), barley, lentils, wheat and chickpeas (Gürsoy \& Güzel, 2010) and maize (Seifi \& Alimardani, 2010).

According Goneli (2008), one of the most important physical changes that occur in agricultural products during drying is the reduction of the external volume. The water loss causes damage to the cell structure of the product, leading to a change in shape and a decrease in their size (Mayor \& Sereno, 2004). Ramos, Brandão, \& Silva (2003) reported that, reducing the water content during the drying process causes a reduction in the size of the cellular tissue, a phenomenon usually called shrinkage. The drying of agricultural products with high initial moisture content, as the fruits of coffee is accompanied by a significant volume reduction, by which the product undergoes alterations in its original dimensions and form and occurs simultaneously with the diffusion of moisture, which can affect the rate of moisture removal. The removal of water decreases the stress exerted by the liquid in the cell walls of the product, causing shrinkage of the material (Fortes \& Okos, 1980). Some authors point to be ignoring the phenomenon of volumetric change during the dehydration process one of the main sources of errors in the development of mathematical models to simulate the drying process of biological materials (Brooker, Bakker-Arkema, \& Hall, 1992; Lang \& Sokhansanj, 1993).

The shrinkage can be very intensive, depending on the drying method used (Krokida \& Maroulis, 1997) and drying conditions, parameters affecting heat transfer and mass and should be considered in establishing models drying (Ramos et al., 2003).

Most models used to represent the drying agricultural products was developed neglecting the shrinkage of the product during the dehydration process (Brooker et al., 1992). Volumetric changes of products, due to their dehydration, are reported to be the main causes of changes in the main physical properties of agricultural products (Ratti, 1994).

Although coffee is an ancient culture, today has developed clonal varieties with unknown physical properties, limited and scattered. In order to obtain data that can be used in systems development processes during harvest and post-harvest coffee, this study aimed to evaluate the shape and shrinkage of coffee fruit during the drying process, and adjust different mathematical models reported in the literature to the experimental values of the analyzed properties, depending on the water content. 


\section{1) Macrothink}

\section{Material and Methods}

This work was performed at the Laboratory of Physical Properties and Quality of Agricultural Products belonging to the National Training Center in Storage (CENTREINAR), located at Universidade Federal de Viçosa, Viçosa, MG.

Coffee fruits (Coffea canephora) were harvested; clone 83 of clonal variety EMCAPA 8141, proceeding from the experimental farm of the Agricultural Research Center of Minas Gerais (EPAMIG), located in the city of Leopoldina, Minas Gerais. The fruit was hand-picked and selected only the two stages, cherry and unripe. During the process of harvesting immature fruits were removed, deteriorated or damaged, in order to obtain a homogeneous material and of better quality, in addition, were used coffee fruit size above the sieve with holes of $9 \mathrm{~mm}$.

Subsequently the different batches of coffee were dried in an oven with forced ventilation with air temperature of approximately $60 \pm 3{ }^{\circ} \mathrm{C}$ until different levels of water content. The monitoring of reduction of the water content with the elapse of drying time was made by gravimetric method (weight loss), knowing the initial moisture content of the product. For this monitoring was used an analytical balance with a precision of $0.01 \mathrm{~g}$. The moisture content of the product was determined by the oven method at $105 \pm 3{ }^{\circ} \mathrm{C}$ to constant weight in three replicates (BRASIL, 2009). During drying, the water content for each obtained samples were homogenized and submitted for determination of its physical properties, always in triplicate.

\subsection{Shape and Size}

The shape and size of the fruits of coffee considered triaxial spheroids (Figure 1) were analyzed by sphericity, circularity, surface area and projected area, from the measurements of the characteristic dimensions, orthogonal axes in ten replicates obtained using a digital caliper with a resolution of $0.01 \mathrm{~mm}$.

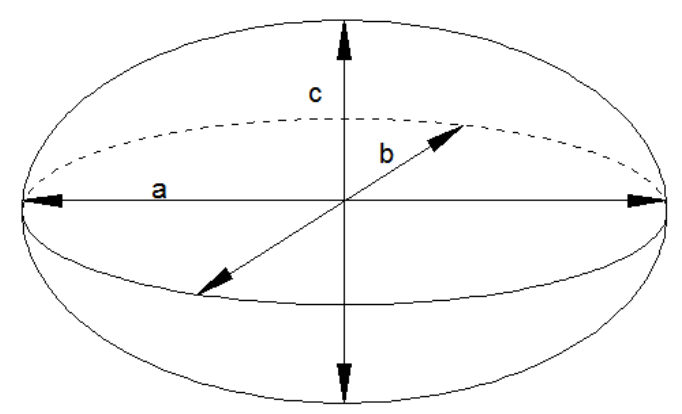

Figure 1. Schematic drawing of the coffee fruit, considered triaxial spheroid, with its characteristic dimensions.

After certain characteristics of its dimensions, volume (V) of fruits was determined as proposed by Mohsenin (1986), according to equation 1: 


$$
V=\frac{\pi a b c}{6}
$$

The sphericity (E) of coffee fruit was calculated using Equation 2, proposed by Mohsenin (1986):

$$
E=\frac{(a b c)^{1 / 3}}{a}
$$

The circularity (C) of coffee fruits was determined equation 3 (Mohsenin, 1986):

$$
C=\frac{b}{a}
$$

The projected area (Ap), in $\mathrm{mm}^{2}$, of coffee fruits was determined by Equation 4:

$$
A_{p}=\frac{\pi a b}{4}
$$

The surface area (S), in $\mathrm{mm}^{2}$, of the fruits of coffee was calculated by the equation 5 and 6 :

$$
\begin{gathered}
S=\frac{\pi b^{2}}{2}+\left(\frac{\pi a b}{2 e}\right) \sin ^{-1} e \\
e=\left[1-\left(\frac{b}{a}\right)^{2}\right]^{1 / 2}
\end{gathered}
$$

\section{Shrinkage rate $(\psi)$}

The rate of shrinkage of coffee fruit during the drying of the product was determined by the ratio between the volume for each water content (V) and the initial volume (Vo) using equation 7:

$$
\Psi=\frac{V}{V_{o}}
$$

where:

$\psi$ : shrinkage rate, decimal;

$\mathrm{V}$ : volume at each water content, $\mathrm{m}^{3}$, and

$\mathrm{V}_{0}$ : initial volume, $\mathrm{m}^{3}$. 


\section{Al Macrothink}

Journal of Agricultural Studies

ISSN 2166-0379

2014, Vol. 2, No. 1

For monitoring the volume reduction of the mass during each measurement, the product was transferred to a measuring cylinder with a capacity of 1 liter. The unit volumetric shrinkage of coffee fruits was determined according to equation 7 . For determining the volume of the product, was used to equation 1 in accordance with Figure 1.

Experimental data of unit volumetric shrinkage and fruit mass were adjusted to the mathematical models described by the expressions listed in Table 1.

Table 1. Models used to simulate the shrinkage rate of agricultural products.

\begin{tabular}{|c|c|c|}
\hline Reference & Model & Eq. \\
\hline Bala e Woods (1984) & $\Psi=1-\beta_{0}\left\{1-\exp \left[-\beta_{1}\left(U_{0}-U\right)\right]\right\}$ & (8) \\
\hline Corrêa et al. (2004) & $\Psi=\frac{1}{\beta_{0}+\beta_{1} \exp [(U)}$ & (9) \\
\hline Rahman (1995) & $\Psi=1+\beta_{1}\left(\mathrm{U}-\mathrm{U}_{0}\right)$ & (10) \\
\hline Linear & $\Psi=\beta_{0}+\beta_{1} U$ & (11) \\
\hline Exponencial & $\Psi=\beta_{1} \exp \left(\left(\beta_{2} U\right)\right.$ & (12) \\
\hline Polynomial & $\Psi=\beta_{0}+\beta_{1} U+\beta_{2} U^{2}$ & \\
\hline
\end{tabular}

where:

$\mathrm{U}$ : water content, \% d.b.;

$\mathrm{U}_{0}$ : an initial moisture content, \% d.b., and

$\beta_{0}, \beta_{1}, \beta_{2}$ : parameters that depend on the product.

\subsection{Statistical analysis}

Experimental data of the variation of water content, shape, size, volumetric shrinkage were subjected to regression analysis (equation 14 and 15) and the selection of the appropriate model to express the relationship between variables.

Linear regression model:

$$
Y_{i}=f\left(X_{i}, \beta\right)+\varepsilon_{i}
$$

here:

$\mathrm{X}_{\mathrm{i}}$ : vector of observations of the predictor variables for the $\mathrm{i}^{\text {th }}$ case;

$\beta$ : vector of parameters;

$\mathrm{f}(\mathrm{Xi}, \beta)$ represents the expected value $\mathrm{E}\left(\mathrm{Y}_{\mathrm{i}}\right)$ and $\varepsilon_{\mathrm{i}}$ : errors. 


\section{I Macrothink}

Nonlinear regression model:

$$
Y_{i}=f\left(X_{i}, \gamma\right)+\varepsilon_{i}
$$

where:

$\gamma$ : vector of model parameters, and

$\mathrm{f}(\mathrm{Xi}, \gamma)$ non-linear function represents the expected value $\mathrm{E}\left(\mathrm{Y}_{\mathrm{i}}\right)$.

The models were selected considering the magnitude of the coefficient of determination $\left(\mathrm{R}^{2}\right)$, the magnitude of the mean relative error $(\mathrm{P})$ and the standard error of estimate (SE). The mean relative error and standard error of the estimate, for each of the models were calculated according to equations 16 and 17:

$$
\begin{gathered}
P=\frac{100}{n} \sum_{i=1}^{n}\left(\frac{|Y-\hat{Y}|}{Y}\right) \\
S E=\sqrt{\frac{\sum_{i=1}^{n}(Y-\hat{Y})^{2}}{G L R}}
\end{gathered}
$$

where:

Y: value observed experimentally;

$\hat{Y}$ : value estimated by the model;

$\mathrm{n}$ : number of experimental observations, and

GLR: degrees of freedom of the model (the number of observations minus the number of model parameters).

\section{Results and Discussion}

Table 2 shows the data of volume, projected area, surface area, rates of shrinkage of the characteristic dimensions (size / initial size), circularity and sphericity of coffee fruits depending on the water content.

Table 2. Shrinkage ratios $\left(a / a_{o}, b / b_{o}\right.$ e $\left.c / c_{o}\right)$, volume $(V)$, the projected area (Ap), the surface area $(\mathrm{S})$, sphericity $(\mathrm{E})$ and circularity $(\mathrm{C})$ of coffee fruits.

\begin{tabular}{|l|c|c|c|c|c|c|c|c|}
\hline $\begin{array}{l}\text { Moist. C. } \\
(\text { d.b. })\end{array}$ & $\begin{array}{c}\mathrm{V} \\
\left(\mathrm{mm}^{3}\right)\end{array}$ & $\begin{array}{c}\mathrm{A}_{\mathrm{p}} \\
\left(\mathrm{mm}^{2}\right)\end{array}$ & $\begin{array}{c}\mathrm{S} \\
\left(\mathrm{mm}^{2}\right)\end{array}$ & $\mathrm{a} / \mathrm{a}_{\mathrm{o}}$ & $\mathrm{b} / \mathrm{b}_{\mathrm{o}}$ & $\mathrm{c} / \mathrm{c}_{\mathrm{o}}$ & $\begin{array}{c}\mathrm{E} \\
(\%)\end{array}$ & $\begin{array}{c}\mathrm{C} \\
(\%)\end{array}$ \\
\hline \multicolumn{10}{|c|}{ Clone 83 cherry } \\
\hline 1,987 & 944,12 & 142,24 & 506,16 & 1,00 & 1,00 & 1,00 & 75,09 & 68,94 \\
\hline 1,300 & 716,44 & 121,87 & 425,75 & 0,96 & 0,90 & 0,89 & 71,68 & 64,70 \\
\hline 0,872 & 592,86 & 107,62 & 368,26 & 0,93 & 0,81 & 0,83 & 69,02 & 60,10 \\
\hline 0,578 & 549,63 & 101,61 & 350,29 & 0,89 & 0,80 & 0,81 & 70,20 & 61,73 \\
\hline 0,364 & 539,03 & 100,23 & 345,73 & 0,89 & 0,80 & 0,81 & 70,29 & 61,86 \\
\hline 0,204 & 537,50 & 99,71 & 343,67 & 0,89 & 0,79 & 0,81 & 70,31 & 61,69 \\
\hline
\end{tabular}




\begin{tabular}{|l|l|l|l|l|l|l|l|l|}
\hline 0,132 & 535,58 & 99,35 & 342,51 & 0,88 & 0,79 & 0,81 & 70,38 & 61,73 \\
\hline \multicolumn{8}{|c|}{ Clone 83 unripe } \\
\hline 1,595 & 544,28 & 99,92 & 336,66 & 1,00 & 1,00 & 1,00 & 67,68 & 56,79 \\
\hline 1,050 & 423,88 & 86,45 & 287,75 & 0,95 & 0,91 & 0,90 & 65,42 & 54,25 \\
\hline 0,696 & 392,50 & 82,30 & 271,84 & 0,94 & 0,87 & 0,88 & 64,40 & 52,67 \\
\hline 0,443 & 378,84 & 79,92 & 265,36 & 0,92 & 0,87 & 0,87 & 65,23 & 53,73 \\
\hline 0,266 & 367,50 & 78,37 & 260,58 & 0,91 & 0,86 & 0,86 & 65,39 & 54,02 \\
\hline 0,114 & 363,95 & 77,77 & 258,71 & 0,90 & 0,86 & 0,86 & 65,49 & 54,13 \\
\hline
\end{tabular}

It can be observed that, reduction for every dimension by reducing the water content. We observe a similar behavior in each shrinkage rate evaluated, which ensures sphericity and roundness values with values close between the beginning and end of drying. Sphericity and circularity were values less than $90 \%$, show that the fruits of coffee conilon cannot be classified as spherical, regardless of water content they present. It is noted that the present Conilon coffee fruits has not uniform variation of its dimensions, with smaller reduction in the major axis (a) when compared with the middle axis (b) and lower (c), as can be seen by varying the shrinkage rate.

It is observed in Figure 2, the behavior of the projected area (Ap) and surface area (S) of coffee fruits in stages unripe and cherry.

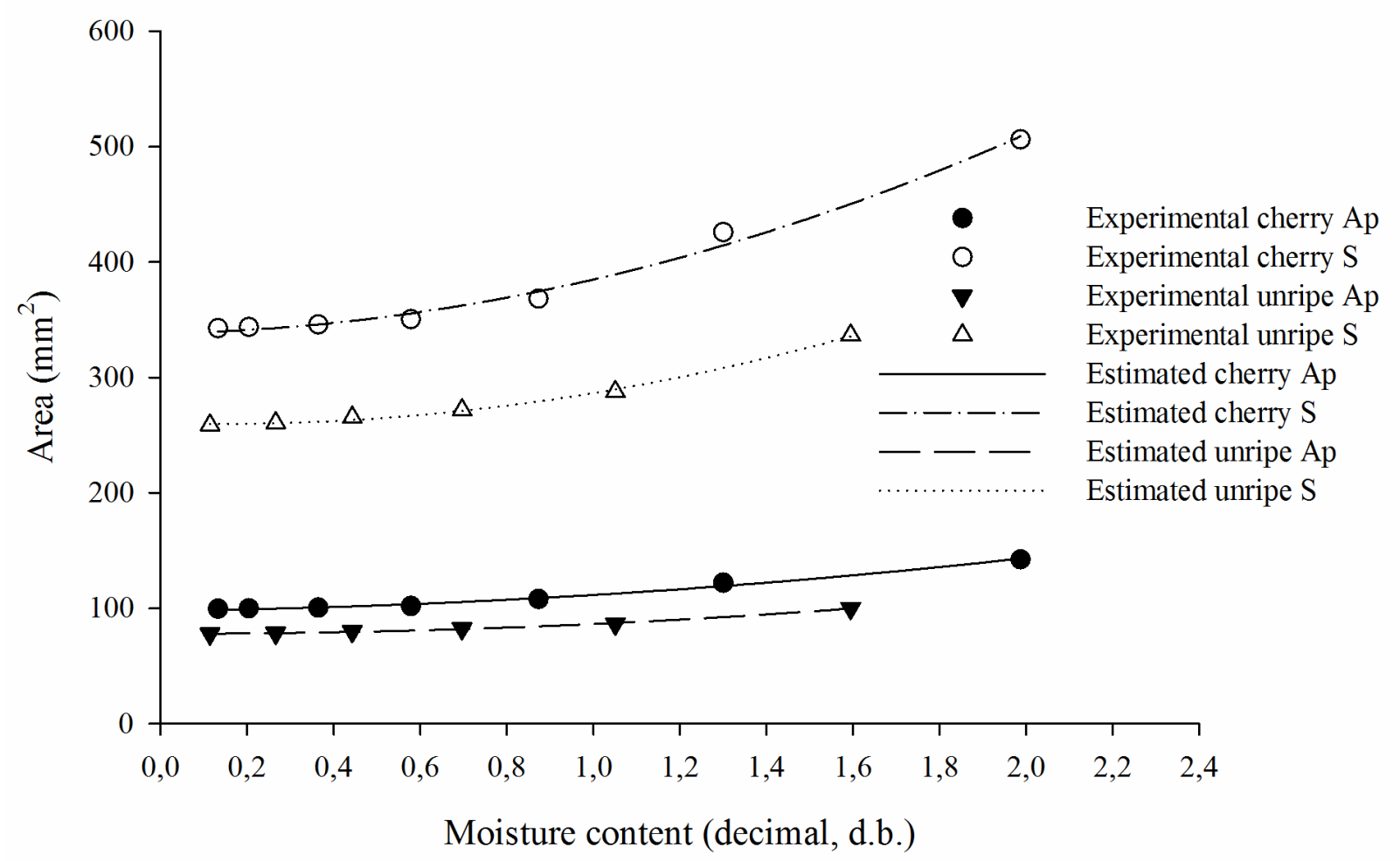

Figure 2. Experimental values and estimated of projected area and surface versus water content of the coffee fruit of the clone 83.

The experimental data of projected area (Ap) and surface area (S) of coffee fruits showed an adjustment to the model with polynomial coefficient of determination greater than 0.99 , as can 
be seen in Table 3 .

Table 3. Coefficients of nonlinear regression models adjusted to the experimental values and calculated projected area (Ap) and surface area (S).

\begin{tabular}{|l|l|l|l|l|l|}
\hline Clone & Phys. prop. & $\beta_{\mathrm{o}}$ & $\beta_{1}$ & $\beta_{2}$ & $\mathrm{R}^{2}$ \\
\hline \multirow{2}{*}{83 cherry } & $\mathrm{A}_{\mathrm{p}}$ & 97,7619 & 4,5654 & 9,1661 & 0,9913 \\
\cline { 2 - 6 } & $\mathrm{S}$ & 338,4011 & 7,1828 & 39,6378 & 0,9906 \\
\hline \multirow{2}{*}{83 unripe } & $\mathrm{A}_{\mathrm{p}}$ & 77,9897 & $-0,6343$ & 8,9379 & 0,9970 \\
\cline { 2 - 6 } & $\mathrm{S}$ & 260,5157 & $-9,3729$ & 35,5574 & 0,9975 \\
\hline
\end{tabular}

Figure 3 shows the behavior of unit shrinkage and mass of coffee fruits in different maturation stages studied.

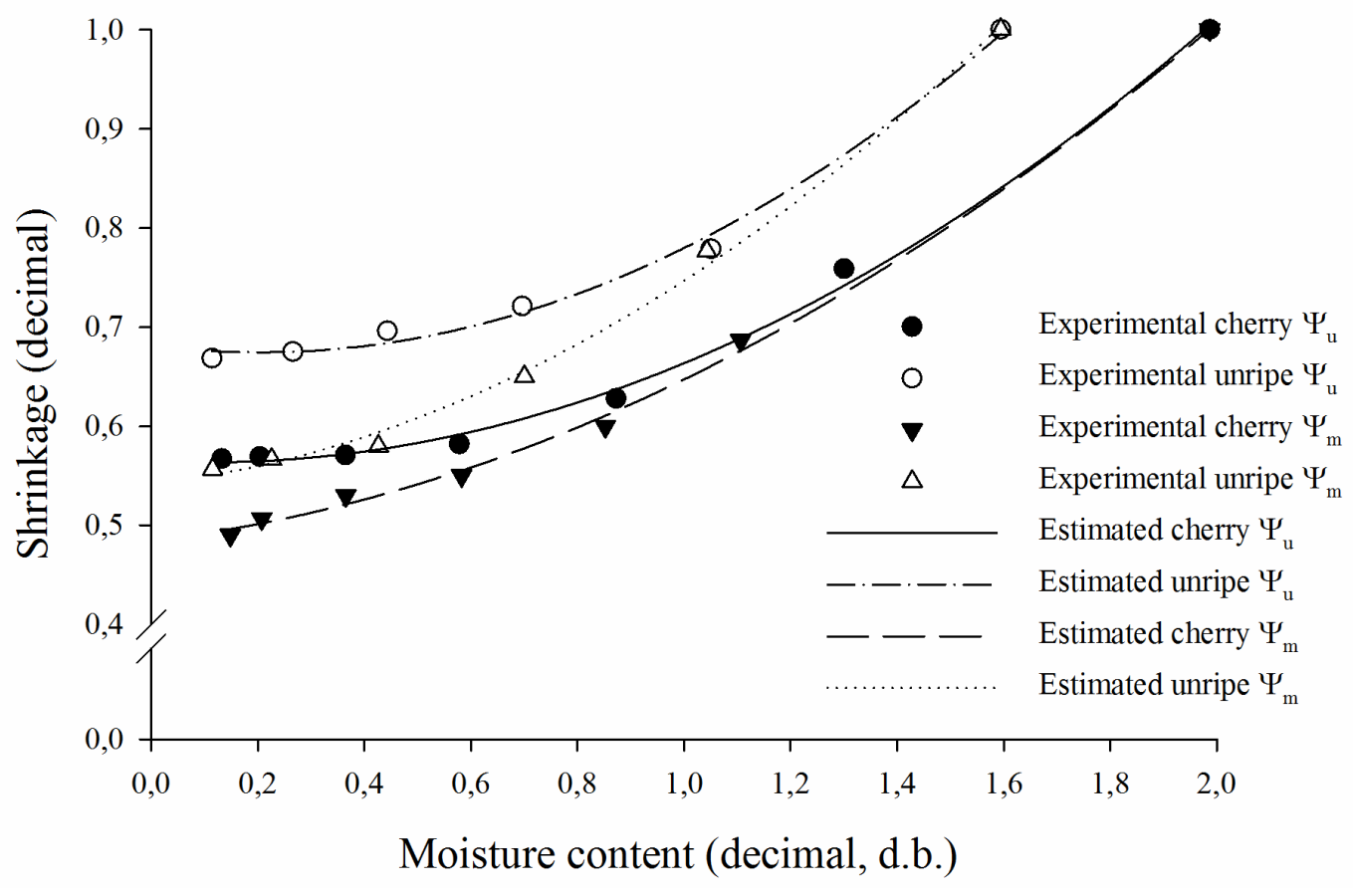

Figure 3. Experimental values and estimated by polynomial model of unit shrinkage and mass as a function of water content of coffee fruits of clone 83 .

It is observed the decrease of the volume of coffee fruit from the decreased water content. The fruits of coffee cherries had a 56.73\% reduction in volume and a reduction of the unripe $66.87 \%$ for the respective moisture content ranges studied. This reduction during the drying process the coffee is associated with shrinkage of the product, filling the pores arising in the course of drying. Similar behavior has been reported by Afonso Júnior (2001), but in this case the contraction of clone 83 was lower compared to the coffee species studied by the author.

Tables 4 and 5, shows the summary of shrinkage models studied for unit shrinkage and mass, respectively. Also presented are the coefficients of determination (R2), mean relative error (P) and standard error of estimate (SE). 
Table 4. Coefficients of unitary shrinkage models adjusted to the experimental values

\begin{tabular}{|l|l|l|l|l|l|l|l|}
\hline Clone & Eq. & $\beta_{\mathrm{o}}$ & $\beta_{1}$ & $\beta_{2}$ & $\mathrm{R}^{2}$ & $\mathrm{SE}$ & $\mathrm{P}$ \\
\hline \multirow{5}{*}{83 cherry } & 8 & 0,5263 & 1,0099 & - & 0,9913 & 0,0165 & $<0,0001$ \\
\cline { 2 - 8 } & 9 & 1,8799 & $-0,1221$ & - & 0,9712 & 0,0301 & $<0,0001$ \\
\cline { 2 - 8 } & 10 & - & 0,2653 & - & 0,8943 & 0,0526 & - \\
\cline { 2 - 8 } & 11 & 0,4886 & 0,2310 & - & 0,9198 & 0,0501 & 0,0006 \\
\cline { 2 - 8 } & 12 & - & 0,5047 & 0,3314 & 0,9594 & 0,0357 & 0,0001 \\
\cline { 2 - 8 } & 13 & 0,5650 & $-0,0255$ & 0,1242 & 0,9967 & 0,0114 & $<0,0001$ \\
\hline \multirow{5}{*}{83 unripe } & 8 & 0,3573 & 1,7314 & - & 0,9993 & 0,0037 & $<0,0001$ \\
\cline { 2 - 8 } & 9 & 1,6495 & $-0,1315$ & - & 0,9991 & 0,0042 & $<0,0001$ \\
\cline { 2 - 8 } & 10 & - & 0,2572 & - & 0,8521 & 0,0483 & - \\
\cline { 2 - 8 } & 11 & 0,6070 & 0,2157 & - & 0,8957 & 0,0454 & 0,0042 \\
\cline { 2 - 8 } & 12 & - & 0,6153 & 0,2826 & 0,9287 & 0,0375 & 0,0020 \\
\cline { 2 - 8 } & 13 & 0,6814 & $-0,0668$ & 0,1654 & 0,9940 & 0,0126 & 0,0005 \\
\hline
\end{tabular}

Table 5. Coefficients of shrinkage models of mass adjusted to the experimental values

\begin{tabular}{|l|l|l|l|l|l|l|l|}
\hline Clone & Eq. & $\beta_{\mathrm{o}}$ & $\beta_{1}$ & $\beta_{2}$ & $\mathrm{R}^{2}$ & $\mathrm{SE}$ & $\mathrm{P}$ \\
\hline \multirow{5}{*}{83 cherry } & 8 & 0,6821 & 0,7398 & - & 0,9974 & 0,0100 & $<0,0001$ \\
\cline { 2 - 8 } & 9 & 2,0596 & $-0,1465$ & - & 0,9616 & 0,0384 & $<0,0001$ \\
\cline { 2 - 8 } & 10 & - & $-0,2982$ & - & 0,9459 & 0,0416 & - \\
\cline { 2 - 8 } & 11 & 0,4200 & 0,2711 & - & 0,9576 & 0,0403 & 0,0001 \\
\cline { 2 - 8 } & 12 & - & 0,4485 & 0,3976 & 0,9893 & 0,0202 & $<0,0001$ \\
\cline { 2 - 8 } & 13 & 0,4843 & 0,0652 & 0,0980 & 0,9979 & 0,0099 & $<0,0001$ \\
\hline \multirow{5}{*}{83 unripe } & 8 & 0,6253 & 0,8779 & - & 0,9942 & 0,0148 & $<0,0001$ \\
\cline { 2 - 8 } & 9 & 1,9572 & $-0,1970$ & - & 0,9645 & 0,0365 & 0,0005 \\
\cline { 2 - 8 } & 10 & - & $-0,3331$ & - & 0,9457 & 0,0404 & - \\
\cline { 2 - 8 } & 11 & 0,4805 & 0,3038 & - & 0,9573 & 0,0400 & 0,0007 \\
\cline { 2 - 8 } & 12 & - & 0,5023 & 0,4243 & 0,9843 & 0,0243 & $<0,0001$ \\
\cline { 2 - 7 } & 13 & 0,5417 & 0,0625 & 0,1427 & 0,9966 & 0,0131 & 0,0002 \\
\hline
\end{tabular}

It can be considered that the models of Bala \& Woods (1984) and modified Corrêa et al. (2004) and polynomial presenting the best fit compared the coefficient of determination and the magnitude of the mean relative error and standard error of the estimate. To analyze the results of the polynomial model was selected because it is the best fit in relation to the aforementioned. Afonso, Corrêa, Pinto, \& Sampaio (2003), in the study of different species and varieties of coffee, showed that the polynomial model was the best fit. Corrêa et al. (2004), turn believe the model Bala and Woods has better fit compared to the experimental values of shrinkage of coffee fruits during the drying process. Other authors, such as Corrêa, Afonso Júnior, Queiroz, Sampaio, \& Cardoso (2002), Resende, Corrêa, Goneli, \& Cecon (2005) and Ribeiro, Corrêa, Rodrigues, \& Goneli (2005) also obs erved that the model of Bala and Woods was the best fit to the experimental data of shrinkage unit for coffee beans, and soy beans, respectively.

It has been determined that the shrinkage decreases during the drying process. McMinn \& 
Magee (1997) attributed this behavior of the product to structural changes associated with cellular changes due to water loss.

\section{Conclusions}

The projected area, surface area and volume increase with increasing water content for Conilon coffee.

The shape of the fruits of Conilon coffee is influenced during the drying process, promoting the reduction of sphericity and circularity values from the reduction of moisture content.

The shrinkage showed a nonlinear decreasing behavior with reducing the water content of the mass of Conilon coffee fruit. The models of Bala \& Woods (1984) adapted Corrêa et al. (2004) and polynomial, fitted to experimental data to estimate unit shrinkage rate and mass fruits of coffee depending on the water content, satisfactorily accounted for the phenomenon, and the polynomial model was the best fit.

\section{Acknowledgement}

The authors gratefully acknowledge the financial support of Coordenação de Aperfeiçoamento de Pessoal de Nível Superior (CAPES), Universidad de Costa Rica (UCR), Ministerio de Ciencia y Tecnología (MICIT) and Consejo Nacional para Investigaciones Científicas y Tecnológicas (CONICIT) of Costa Rica.

\section{References}

Afonso Júnior, P. C. (2001). Aspectos físicos, fisiológicos e de qualidade do café em função da secagem e do armazenamento. Doctor. Universidade Federal de Viçosa.

Afonso, P., Corrêa, P., Pinto, F. A., \& Sampaio, C. (2003). Shrinkage Evaluation of Five Different Varieties of Coffee Berries during the Drying Process. Biosystems Engineering, 86(4), 481-485. http://dx. doi.org/10.1016/j.biosystemseng.2003.08.012

Al-Mahasneh, M. A., \& Rababah, T. M. (2007). Effect of moisture content on some physical properties of green wheat. Journal of Food Engineering, 79(4), 1467-1473. http://dx. doi.org/10.1016/j.jfoodeng.2006.04.045

Amin, M. N., Hossain, M. A., \& Roy, K. C. (2004). Effects of moisture content on some physical properties of lentil seeds. Journal of Food Engineering, 65(1), 83-87. http://dx.doi.org/10.1016/j.jfoodeng.2003.12.006

Bala, B. K., \& Woods, J. L. (1984). Simulation of deep bed malt drying. Journal of Agricultural Engineering Research, 30, 235-244. http://dx.doi.org/10.1016/S0021-8634(84)80024-4

BRASIL. (2009). Regras para análise de sementes. Brasilia: LANARV/SNAD/MA (p. 399). Brasilia.

Brooker, D. B., Bakker-Arkema, F. W., \& Hall, C. W. (1992). Drying and Storage of Grains and Oilseeds. (p. 450). New York: Van Nostrand Reinhold. 


\section{Mll Macrothink}

Journal of Agricultural Studies ISSN 2166-0379 2014, Vol. 2, No. 1

Chandrasekar, V. (1999). Physical and Thermal Properties of Coffee. Journal of Agricultural Engineering Research, 73(3), 227-234. http://dx.doi.org/10.1006/jaer.1999.0411

Corrêa, P. C., Afonso Júnior, P. C., Queiroz, D. M. De, Sampaio, C. P., \& Cardoso, J. B. (2002). Variação das dimensões características e da forma dos frutos de café durante o processo de secagem. Revista Brasileira de Engenharia Agrícola e Ambiental, 6(3), 466-470. http://dx.doi.org/10.1590/S1415-43662002000300014

Corrêa, P. C., Ribeiro, D. M., Resende, O., Afonso Júnior, P. C., \& Goneli, A. L. D. (2004). Mathematical modeling for representation of coffee berry volumetric shrinkage. International Drying Symposium. São Paulo.

Corrêa, P. C., Ribeiro, D. M., Resende, O., \& Botelho, F. M. (2006). Determinação e modelagem das propriedades físicas e da contração volumétrica do trigo, durante a secagem. Revista Brasileira de Engenharia Agrícola e Ambiental, 10(31), 665-670.

Fonseca, A. F. A. (2001). Variedades derivadas de café conilon (Coffea Canephora) desenvolvidas pelo INCAPER para o Espírito Santo. II Simpósio de Pesquisa dos Cafés do Brasil. Vitória, Espírito Santo.

Fortes, M., \& Okos, M. R. (1980). Drying theories. Advances in Drying. New York: Hemisphere Publishing.

Goneli, A. L. D. (2008). Variação das propriedades físico-mecânicas e da qualidade de mamona (Ricinus communis L.) durante a secagem e o armazenamento. Tese (Doutorado em Engenharia Agrícola) - Universidade Federal de Viçosa. Viçosa.

Gürsoy, S., \& Güzel, E. (2010). Determination of Physical Properties of Some Agricultural Grains. Research Journal of Applied Sciences, Engineering and Technology, 2(5), 492-498.

Ivoglo, M. G. (2007). Divergência genética entre progênies de café robusta. Tese de doutorado. Instituto Agronômico de Campinas. (If this is a thesis work mention it after the title)

Kashaninejad, M., Mortazavi, A., Safekordi, A., \& Tabil, L. G. (2006). Some physical properties of Pistachio (Pistacia vera L.) nut and its kernel. Journal of Food Engineering, 72(1), 30-38. http://dx.doi.org/10.1016/j.jfoodeng.2004.11.016

Krokida, M. K., \& Maroulis, Z. B. (1997). EFFECT OF DRYING METHOD ON SHRINKAGE AND POROSITY. Drying Technology, 15(10), 2441-2458. http://dx.doi.org/10.1080/07373939708917369

Lang, W., \& Sokhansanj, S. (1993). BULK VOLUME SHRINKAGE DURING DRYING of WHEAT and CANOLA. Journal of Food Process Engineering, 16(4), 305-314. http://dx.doi.org/10.1111/j.1745-4530.1993.tb00323.x

Mayor, L., \& Sereno, A. M. (2004). Modelling shrinkage during convective drying of food materials: a review. Journal of Food Engineering, 61(3), 373-386. http://dx.doi.org/10.1016/S0260-8774(03)00144-4

McMinn, W. A. M., \& Magee, T. R. A. (1997). Physical characteristics of dehydrated potatoes - Part II. Journal of Food Engineering, 33, 37-48. 


\section{Macrothink}

Journal of Agricultural Studies

ISSN 2166-0379

2014, Vol. 2, No. 1

Mohsenin, N. N. (1986). Physical properties of plant and animal materials. (p. 841). New York: Gordon and Breach Publishers.

Perez-Alegria, L. R., Ciro, H. J., \& Abud., L. C. (2001). Physical and thermal properties of parchment coffee bean. Transactions of the ASAE, 44(6), 1721-1726.

RAHMAN, S. (1995). Food properties handbook (p. 500). Boca Ratón: CRC Press LLC.

Ramos, I. N., Brandão, T. R. S., \& Silva, C. L. M. (2003). Structural Changes During Air Drying of Fruits and Vegetables. Food Science and Technology International, 9(3), 201-206. http://dx.doi.org/10.1177/1082013030335522

Ratti, C. (1994). Shrinkage during drying of foodstuffs. Journal of Food Engineering, 23(1), 91-105. http://dx.doi.org/10.1016/0260-8774(94)90125-2

Resende, O., Corrêa, P. C., Goneli, A. L. D., \& Cecon, P. R. (2005). Forma, tamanho e contração volumétrica do feijão (Phaseolus vulgaris L.) durante a secagem. Revista Brasileira de Produtos Agroindustriais, 7(1), 15-24.

Resende, O., Corrêa, P. C., Goneli, A. L. D., \& Ribeiro, D. M. (2008). Propriedades físicas do feijão durante a secagem: determinação e modelagem. Ciência e Agrotecnologia, 32(1), 225-230. http://dx.doi.org/10.1590/S1413-70542008000100033

Ribeiro, D. M., Corrêa, P. C., Rodrigues, D. H., \& Goneli, A. L. D. (2005). Análise da variação das propriedades físicas dos grãos de soja durante o processo de secagem. Ciência $e$ Tecnologia de Alimentos, 25(3), 611-617. http://dx.doi.org/10.1590/S0101-20612005000300035

Seifi, M., \& Alimardani, R. (2010). The Moisture Content Effect on Some Physical and Mechanical Properties of Corn (Sc 704). Journal Of Agricultural Science, 2(4), 125. http://dx.doi.org/10.5539/jas.v2n4p125

Teixeira, M. M. (2011). Influência dos diferentes processos de pós-colheita na agregação de valor do café conilon. Universidade Federal do Espírito Santo.

Varnamkhasti, M. G., Mobli, H., Jafari, A., Keyhani, A. R., Soltanabadi, M. H., Rafiee, S., \& Kheiralipour, K. (2008). Some physical properties of rough rice (Oryza Sativa L.) grain. Journal of Cereal Science, 47(3), 496-501. http://dx.doi.org/10.1016/j.jcs.2007.05.014

\section{Copyright Disclaimer}

Copyright reserved by the author(s).

This article is an open-access article distributed under the terms and conditions of the Creative Commons Attribution license (http://creativecommons.org/licenses/by/3.0/). 